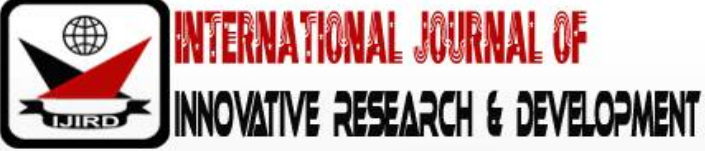

ISSN 2278 - 0211 (Online)

\section{Assessment of Housing Quality and Environmental Degradation in Awka, Anambra State, Nigeria}

\author{
Okafor Johnbosco Ikenna \\ Graduate Assistant, Department of Estate Management, Nnamdi Azikiwe University, Nigeria \\ Keke Onyinye Vivian \\ Lecturer, Department of Estate Management, Nnamdi Azikiwe University, Nigeria \\ Efobi Dumebi Jessica \\ Assistant Lecturer, Department of Estate Management, Anambra State University, Nigeria
}

\begin{abstract}
:
Housing represents one of the most basic human needs and has no doubt, a profound impact on the health, welfare and productivity of individual. It includes both the physical structure of a building, the services provided in the building as well as the surrounding. There is therefore the need for a certain level of standardization of the structure as well its facilities for human and environmental functionality. This paper studies the housing quality of Awka, the capital city of Anambra State and its resultant effect of environmental degradation therein. Exploratory survey was conducted and data collected were analysed using tabular, pictoral and Pearson's chi-square analytical technique. The study revealed that even though some areas in Awka had adequate housing, there were some other areas with poor quality houses which have resulted in the degradation of such environment. It was recommended that Government should make available, infrastructural facilities such as, electricity supply, access road, good drainage system, etc., in order to make the environment conducive and improve on its housing quality.
\end{abstract}

Keywords: Housing, housing quality, environment, environmental degradation, Awka, Anambra State

\section{Introduction}

Housing is one of the three basic necessities of mankind and it is the most important factor needed for the physical survival of man after the provision of food. Hence, housing is one of the best indicators of a person's standard of living and his place in the society (Ibimilua and Ibitoye, 2015). Similarly, Fadamiro, Taiwo and Ajayi (2004) noted that housing is very fundamental to the welfare, survival and health of man; its major function being to protect man from bad weather, wild animal and other environmental factors that could affect or attack man. Housing includes the physical structure and the amenities in the building which makes it functional. The amenities provided in the structure contribute to the quality of the house, and this in turn affects the functionality and the convenience of such building to the user. The World Health Organization (1961) stated that a good house should comprise of; a good roof to keep out the rain, good walls and doors to protect against bad weather and to keep out animals, sunshades all around the house to protect it from direct sunlight in hot weather, as well as wire nettings at windows and doors to keep out insects like house flies and mosquitoes. Housing quality embraces many factors which include the physical condition of the building and other facilities and services that make living in a particular area conducive. The quality of housing within any neighbourhood should be such that satisfies minimum health standards and good living standard, but should also be affordable to all categories of households (Okewole and Aribigbola, 2006). In other words, housing quality can be judged from the physical appearance of the buildings, facilities provided, quality of wall used in the building construction, eminence of the roofing materials, condition of other structural components of the house, and environmental condition of the house. Qualitative and quantitative housing deficiencies in Nigeria cities have been attributed to rapid urban growth (Ahianba, 2008). Nigerian cities face a myriad of housing problems manifested in the form of housing shortages, poor housing quality, high rental charges and poor environmental quality, the wide margin between effective demand for and supply of housing ensures that many urban residents in the country continue to live in sub-standard structure unsuitable for human habitation (Olanrewaju,2012). Housing deficit in Nigeria has been estimated at between 12 - 14 million housing units (Adeniyi, 2008).This deficit of housing explains the reason for excess pressure being mounted on the existing housing facilities because the existing housing facilities serves more number of persons than it was original design to serve, this will depreciate the housing facility faster and this will directly or indirectly affect the environment negatively. For example, a house which is designed to serve five persons but is used by ten persons, will affect the drainage system and other waste management facilities and as such pollute the environment.

The unwise use of the natural environment due to ignorance, poverty, overpopulation and urbanization amongst others has led to the degeneration of the environment. The charges (degeneration) occur as Nigerians attempt to adjust 
their seemingly endless wants and desires for food, shelter, recreation, infrastructural facilities, and so on (NEST, 1992). These land use activities contribute to the overall development of the country but they equally produce negative impact on the environment. These negative impacts are referred to as environmental degeneration which implies "abuse of the environment" due to improper resources management.

\section{Awka Housing Quality and Its Environment}

The inadequacy of housing in terms of quality and quantity results in poor standard of the environment. In Nigeria, most people live in poor quality housing and in unsanitary environments (Olayiwola, Adeleye and Ogunsakin, 2005). This problem of inadequate housing has been compounded by the rapid rates of urbanization and economic growth. It is sad that in Nigeria, urbanization which is supposed to be a major force for modernization and rapid economic growth has rather resulted in massive unemployment, slum development, environmental degradation and high poverty levels (UN-Habitat, 2008b, Gbadegesin and Aluko, 2010).The situation is not different in major urban centres of the country particularly in Awka, the state capital of Anambra State. The housing situation in Anambra State as Ugonabo and Emoh (2013) observed has been in a deplorable state since its creation in 1991. Since the creation of Anambra state, and the subsequent making of Awka as its capital, the city has been experiencing continues growth in population due to migration of people from various location into the capital city and natural increase. Urbanization which is as a result of increase in population of people in a particular area has led to the increase in demand for housing in Awka since it was made capital of Anambra state in 1991. The high influx of people has inevitably resulted in a high demand for housing, most especially for residential housing units. This in turn has resulted in overcrowding, poor and inadequate social amenities, unsatisfactory and unwholesome environmental conditions and urban squalor, the absence of open space, the over development of land area leading to the overcrowding of buildings, in-accessibility within residential areas, and in the scarcity and high cost of building materials (Onibokun, 1985).

\subsection{Causes of Environmental Degradation in Housing Development}

The unwise use of the natural environment due to ignorance, poverty, overpopulation and urbanization amongst others has led to the degradation of the environment. These changes occur as individuals attempt to adjust their seemingly endless wants and desires for food, shelter, recreation, infrastructural facilities, and so on (NEST, 1992). These land use activities contribute to the overall development of the society but they equally produce negative impact on the environment. These negative impacts are referred to as environmental degradation which implies "abuse of the environment" due to improper natural resources management. A major cause of environmental degradation in most urban cities is urbanization. As a result of urbanization and lack of economic opportunities in rural areas, many people move to the cities. They move to the cities that are already dealing with issues of overcrowding, infrastructure and high cost of living (Lanrewaju, 2012). This forces them to seek shelter in slums.

United Nation Habitat in 2006 found that $90 \%$ of slum residents are in the developing countries with struggling economies. The fact is these cities were not meant to handle millions of people streaming in when designed. This impact the availability and affordability of housing, forcing millions to live in substandard dwellings. Environmental conditions in Awka city just as in many other parts of the country has gradually deteriorated due to the rapid growth of the cities and the attendant inability of social services and infrastructures to keep pace with the rate of growth in population (Lanrewaju, 2012). No doubt, Awka has in recent times, witnessed rapid rate of development by way of infrastructure (roads, bridges, flyovers, housing estates) but it is however not enough to meet the needs of the growing population of the city.

\subsubsection{Other Causes of Environmental Degradation as They Affect Housing Quality in Awka, Anambra State Include}

\subsubsection{Non-Compliance with Building Regulations and Bye-Laws}

According to Ugonabo (2012), extensive illegal and unregulated building patterns dominate the urban towns in the state capital of Anambra state. Housing structures are built without any regard to the existing building and health codes or zoning and sub-division regulations- thus creating slum and squatter conditions in which most residents live. This ugly and unpleasant situation still persists today and not much has been done by the government to increase the quality of housing stock in relation to its demand. The cost of building construction is continually on the increase and it is becoming more difficult and demanding for an average civil servant to build quality houses unless government begins to partner with the private sector and take necessary steps to this problem.

Building regulations such as zoning, set back, etc. are regulations to guide our system and type of building so as not to build haphazardly in order to keep the environment in a good state. But it is unfortunate that in our urban centers such as Awka capital, people now build as they like without obtaining planning permit to build a particular kind of building which is in line with the zoning of the area. This has drastically depreciated the aesthetic and economic value of our urban environment as there is no longer proper planning for housing. The combination of residential, industrial and commercial property in the same locality is now the order of the day in capital city. This is not good for a developing urban environment because of the simultaneous release of waste from the industrial, commercial and residential property.

\subsubsection{Overcrowding}

In large urban centers poor housing conditions often manifest in the high numbers of people living in one room and paying exorbitant rents. This is physical overcrowding, which is a determinant of two major types of problems namely, a health hazard and harmful social behavior. Overcrowding is a hazard to health where sleeping accommodation is 
congested and ventilation is poor. Infectious (air and water borne) diseases spread very fast under such conditions (Odongo, 1979). This is the condition of housing in most part of Awka metropolis especially areas dominated by low income earners, some student areas within the city which have gradually turned into slum areas. This negatively affects the environment as a result of excess generation of waste above the quantity the environment can manage.

\subsubsection{Inadequate Basic Infrastructural Amenities}

Osuide and Dimuna (2005) noted that the urbanization process in many developing countries particularly Nigeria, has not been accompanied with a corresponding supply of adequate houses, basic amenities and infrastructures. This is the same situation obtainable in Awka the state capital of Anambra state. A standard house is expected to have a bathroom, WC, septic tank, soak-away pit, light and water. A situation where by all this is not provided in a house, the solid waste generated from the building will either be channelled into the river or used in dirtying the environment. This act could destroy the aquatic environment and degenerate the terrestrial environment.

\subsubsection{Poor Ventilation in Buildings}

Izomoh (2005) cited that most residential buildings have been designed and constructed with little or no consideration for the thermal comfort through the process of cross-ventilation.Ventilation entails the proper positioning of doors and windows in a house so as to permit the entrance of air into the building. A situation where such provision is not made available, the building will not be conducive for human habitation as various kinds of offensive odour would be produced from the house and be hazardous to human health.

\subsubsection{Improper Management of Waste.}

Michael (1996) have it that about 130,000 deaths and over 50millions cases of respiratory infections annually result from air pollution in cities of the developing world. This is so because most inhabitants of these cities engage in indiscriminate disposal of waste. The wastes generated from most urban houses are sometimes not properly disposed. It is either the waste is burnt which will cause air pollution or it is dumped carelessly at the waste dump there by exposing people to inhaling bad odour emitting from the waste. Waste dump centresare to be located far away from human habitation as closeness to it could aid the spread of diseases.

\subsection{Effect of Environmental Degradation on Housing Quality}

The rapid increase in the population of the urban centers has resulted in an increase in the cost of living, because of higher demand on urban commodities that are getting shorter in supply by the day. Thus, there is a dearth and high cost of urban land, and high cost of housing, which is often in short supply and out of the economic reach of the majority of the urban households who incidentally fall into the low-income category. There is a dearth and high cost of urban land, and high cost of housing, which is often in short supply and out of the economic reach of the majority of the urban households (Oladapo and Olotuah, 2007) this explains the reason why agreater percentage of the poor in the urban area lives in the slum area of the city. This is mainly because substandard accommodation there is very cheap and the neighbourhoods are in close proximity to their work places.

Substandard housing is the type of housing that does not meet the standards for living by people. These standards are usually set by governments and deal with how safe the dwelling is for people to live. For example, there may not be appropriate heating, plumbing, electricity or proper sanitation. Often substandard housing is deteriorated housing that has not been repaired or temporary housing that does not meet building codes.

\section{Research Methodology}

The study was carried out on landlords and tenants of selected buildings as well as Estate Surveyors and Valuers practising in Awka capital city. A sample size of 100 (one hundred) respondents was used and questionnaires distributed to them. Also, interview was granted by the relevant official(s) of The Anambra State Housing Corporation, particularly the Estate Department. Studieswere also carried out on the effort of the Anambra State Waste Management Agency and the Anambra State Urban Development Board in improving the environment.

\section{Discussion of Data Analysis}

Out of the 100 questionnaires distributed, 70 were successfully retrieved with the following analysis.

\begin{tabular}{|c|c|c|c|}
\hline Option & Number Distributed & Number Retrieved & Percentage \\
\hline $\begin{array}{c}\text { Occupiers Of Residential Houses (Landlords } \\
\text { \& Tenants) }\end{array}$ & 86 & 60 & $85.71 \%$ \\
\hline $\begin{array}{c}\text { Professionals (Estate Surveyors And } \\
\text { Valuers) }\end{array}$ & 14 & 10 & $14.29 \%$ \\
\hline Total & 100 & 70 & $100 \%$ \\
\hline
\end{tabular}

Table 1: Housing Status of Respondents

Source: Field Survey, 2019 


\begin{tabular}{|c|c|c|}
\hline Option & Number & Percentage \\
\hline Very Good & 4 & $5.7143 \%$ \\
\hline Good & 32 & $45.71 \%$ \\
\hline Fair & 19 & $27.143 \%$ \\
\hline Poor & 12 & $17.143 \%$ \\
\hline Undecided & 3 & $4.286 \%$ \\
\hline Total & 70 & $100 \%$ \\
\hline
\end{tabular}

Table 2: Present State of Housing in Awka Capital City

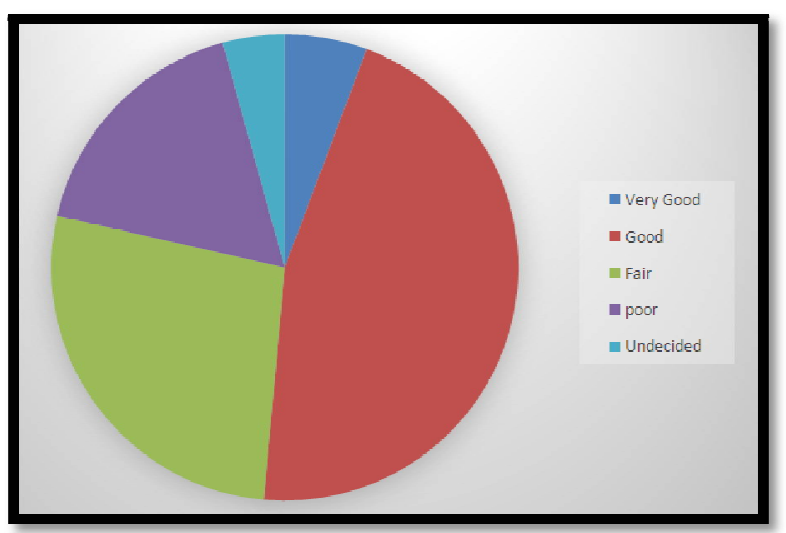

Figure 1

Source: Field Survey, 2019

\begin{tabular}{|c|c|c|c|c|c|c|c|c|}
\hline Causes & Sa & A & UD & D & SD & Number & Mean & Remark \\
\hline Urban Poverty & 6 & 27 & 17 & 13 & 7 & 70 & 3.2 & Accepted \\
\hline Lack Of Access To Land & 7 & 27 & 15 & 12 & 9 & 70 & 3.2 & Accepted \\
\hline Over Crowding & 15 & 17 & 16 & 12 & 10 & 70 & 3.2 & Accepted \\
\hline $\begin{array}{c}\text { Non-Compliance To } \\
\text { Building Regulations }\end{array}$ & 42 & 21 & 6 & 0 & 1 & 70 & 4.64 & Accepted \\
\hline Poor Ventilation & 14 & 18 & 23 & 10 & 5 & 70 & 3.37 & Accepted \\
\hline
\end{tabular}

Table 3: Causes of Poor Housing Quality and Environmental Degeneration in Awka Capital City

Source: Field Survey, 2019

\begin{tabular}{|c|c|c|c|c|c|c|c|c|}
\hline Effects & Sa & A & UD & D & SD & Number & Mean & Remark \\
\hline It Aids The Spread Of Disease & 27 & 26 & 15 & 2 & 0 & 70 & 4.11 & Accepted \\
\hline It Reduces Property Value & 32 & 18 & 10 & 6 & 4 & 70 & 3.97 & Accepted \\
\hline $\begin{array}{c}\text { It Makes The Environment To Be } \\
\text { Unconducive }\end{array}$ & 36 & 18 & 9 & 3 & 4 & 70 & 4.13 & Accepted \\
\hline
\end{tabular}

Table 4: Effects of Environment Degeneration

Source: Field Survey, 2019

\subsection{Respondents View on Other Causes of Environmental Degeneration in Awka Capital City}

In the table below $15(21.43 \%)$ respondents were of the view that bad road network has contributed to environmental degeneration in Awka, 11 (15.714\%) are of the view that it is lack of proper drainage system, $18(25.714 \%)$ are of the opinion that indiscriminate dumping of refuse has done harm to the environment, $5(7.143 \%)$ agrees that it is overcrowding which has contributed majorly to environmental degeneration in Awka capital city, $10(14.286 \%)$ are of the view that improper planning is the cause of environmental degeneration while $11(15.714 \%)$ are of no opin

\begin{tabular}{|c|c|c|}
\hline Causative factor & Number & Percentage \\
\hline Bad road network & 15 & $21.43 \%$ \\
\hline Lack of proper drainage system & 11 & $15.714 \%$ \\
\hline Indiscriminate dumping of refuse & 18 & 25.714 \\
\hline Overcrowding & 5 & $7.143 \%$ \\
\hline Improper planning & 10 & $14.286 \%$ \\
\hline None of the above & 11 & $15.714 \%$ \\
\hline Total & 70 & $100 \%$ \\
\hline
\end{tabular}

Table 5: Other Factors That Have Caused Environmental Degeneration in Awka Capital City.

Source: Field Survey, 2019 


\subsection{Respondents View on the Result of Poor Housing Quality on the Environment}

In the table below, majority of the respondents agreed that poor housing quality has contributed to environmental degradation in Awka capital city. This is signified by the mean which is above 3.0.

\begin{tabular}{|c|c|c|c|c|c|c|c|c|}
\hline $\begin{array}{c}\text { Poor Housing Quality Has Resulted to Environmental } \\
\text { Degeneration in Awka Capital Ciy }\end{array}$ & SA & A & UD & D & SD & Number & Mean & Remark \\
\hline & 29 & 31 & 4 & 4 & 2 & 70 & 4.16 & Accepted \\
\hline
\end{tabular}

Table 6: Effect of Poor Housing Quality Has Resulted to Environmental Degeneration in Awka Capital City Source: Field Survey, 2019

4.3. Respondents View on the Solution to the Problem of Housing Quality in Awka Capital City

In the table below the mean of all the possible solution to poor housing quality is above 3.0. therefore, we will accept constant inspection of houses, demolition of unapproved building and sensitization against burning of domestic waste has a solution to poor housing quality in Awka capital city.

\begin{tabular}{|c|c|c|c|c|c|c|c|c|}
\hline Solution & SA & A & U & D & SD & Number & Mean & Remark \\
\hline Constant inspection of houses & 36 & 16 & 11 & 3 & 2 & 70 & 4.2 & Accepted \\
\hline $\begin{array}{c}\text { Demolition of unapproved houses } \\
\text { Sensitization against burning of domestic } \\
\text { waste }\end{array}$ & 20 & 26 & 16 & 2 & 6 & 70 & 3.7 & Accepted \\
\hline \begin{tabular}{c} 
waccepted \\
\hline
\end{tabular} & & 17 & 0 & 3 & 70 & 4.7 & Acced \\
\hline
\end{tabular}

Table 9: Solutions to the Problem of Poor Housing Quality

Source: Field Survey, 2019

\subsection{Respondents View on the Effort of the Government towards Improvement of Housing Quality in Awka}

In the table below and analysis, it appears that the government has been making earnest effort in combating poor housing quality and also fighting environmental degeneration in the state capital. But it appears that the effort of the government has either not been yielding much or it has not gotten to some locations in the state capital. Such areas still experience environmental degeneration which is sometimes as a result of poor housing quality.

\begin{tabular}{|c|c|c|c|c|c|}
\hline Option & SA & A & UD & D & SD \\
\hline Number (x) & 14 & 25 & 2 & 18 & 11 \\
\hline Mean weight (f) & 5 & 4 & 3 & 2 & 1 \\
\hline FX & 70 & 100 & 6 & 36 & 11 \\
\hline
\end{tabular}

Table 7: Efforts of Government Agencies to Improve the Housing Quality of Awka Capital City

Source: Field Survey, 2019

$$
\begin{gathered}
\text { Mean }=\sum F x \div \sum X \\
\text { Mean }=223 \div 70 \\
\text { Mean }=3.19 \\
\text { Remark: Accepted }
\end{gathered}
$$

\subsection{Respondents View on the Future of Housing Quality of Awka Capital City}

In the table and pie chart below, it appears that housing quality can be improved in Awka capital city. But this is conditional to the fact that both the government and individual will have to corporate and ensure that the agencies in charge of housing in Anambra state are up and doing and also that the people will have to comply to the building codes and regulation stipulated by the Anambra State Urban Development Board (ASUDEB).

\begin{tabular}{|c|c|c|}
\hline Opinion & Number & Percentage \\
\hline Very Good & 9 & $12.857 \%$ \\
\hline Good & 35 & $50 \%$ \\
\hline Fair & 15 & $21.43 \%$ \\
\hline Poor & 7 & $10 \%$ \\
\hline Undecided & 4 & $5.7 \%$ \\
\hline Total & 70 & $100 \%$ \\
\hline
\end{tabular}

Table 8: Future Projections for Awka Housing Sector Source: Field Survey, 2019 


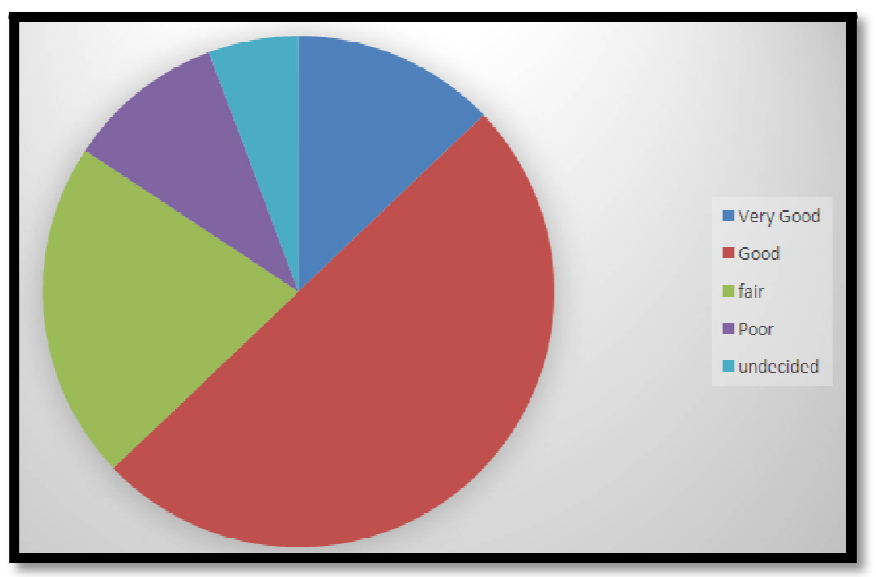

Figure 2

Source: Field Survey, 2019

\subsection{Test of Hypothesis}

- $\mathrm{H}_{0}$ : Housing quality has no significant relationship with environmental degeneration in Awka capital city

\begin{tabular}{|c|c|c|c|c|c|c|}
\hline Mean Response & Mean Weight & Observe(oi) & Expected (ei) & Oi-ei & (oi-ei) $^{\mathbf{2}}$ & (oi-ei) $^{2} \div \mathbf{- i}$ \\
\hline SA & 5 & 29 & 14 & 15 & 225 & 16.07 \\
\hline A & 4 & 31 & 14 & 17 & 289 & 20.64 \\
\hline UN & 3 & 4 & 14 & -10 & 100 & 7.143 \\
\hline D & 2 & 4 & 14 & -10 & 100 & 7.143 \\
\hline SD & 1 & 2 & 14 & -12 & 144 & 10.285 \\
\hline Total & & 70 & 70 & & 858 & 61.281 \\
\hline
\end{tabular}

Table 9

Source: Field Survey, 2019

Degree of freedom $=5-1=4$

Level of significance $=0.05$

Critical value $=9.49$

Calculated value $=61.281$

From the above analysis, the calculated value is higher than the critical value hence we reject the null hypothesis. This implies that there is a significant relationship between housing quality and environmental degeneration in Awka capital city

\section{Findings and Recommendations}

The research study has been able to reveal that the present state of housing quality in Awka capital city is not perfectly good, but approximately on the average. This is to say that there are still a good number of areas in Awka that is suffering poor housing quality, despite the effort of the government in improving the quality of houses. It was also discovered that factors such as, urban poverty, lack of access to land, overcrowding, non-compliance to building codes and regulations and poor ventilation has contributed to poor housing quality in Awka capital city. Poor housing quality has resulted to environmental degeneration in most of the areas affected. The effect of this environmental degeneration on both the occupants of the property and the property itself includes, spread of disease, reduction in property value and unhealthy environment. Apart from poor housing quality, there are some other causes of environmental degeneration which includes, bad road network lack of good drainage system, indiscriminate dumping of waste, etc.

Government, through the establishment of appropriate housing and environmental agencies, constant inspection of houses, demolition of unapproved houses sensitization against burning of domestic waste or inappropriate disposal of domestic waste can help savage the poor condition of housing and also improve the environment. The fight against poor housing quality and environmental degeneration is not a fight for the government alone but also requires the collective effort of private individual.

- Finally, the test of hypothesis proved that there was significant relationship between housing quality and environmental degeneration in Awka capital city.In view of the findings, the following recommendations were put forward.

- Government should make available infrastructural facilities such as, electricity supply, access road, good drainage system so as to make the environment conducive for the development of quality houses.

- Government agencies should also embark on proactive duties such as constant inspection of houses, demolition of unapproved buildings and sensitization of the people against inappropriate disposal of waste so as to combat poor housing quality leading to environmental degeneration.

- Government however cannot fight this alone; individuals should support the government by, complying to the building codes and regulations, properly ventilate their houses and dispose domestic waste in the proper manner. 
- No form of development can take place without land; hence there is need to create less difficulty in the acquisition of land. This can be achieved through the reduction in the cost of land registration and titling, elimination of the bottlenecks found in the land registry, land allocation by the government at a reduced cost. This will help to increase the development of good housing quality and eradicate overcrowding.

\section{Conclusion}

From the discussion so far, it appears that the effort made by the government and its agencies have not being able to eradicate the problem of poor housing quality in Awka capital city, some of the areas are still having the issue of poor housing quality which has resulted in environmental degeneration of such area. Agencies in charge of housing and environment need to be more proactive in carrying out their duty, and also make the people see the importance of having quality houses and a healthy environment. Once the problem of poor housing quality is handled effectively, the rate of environmental degeneration will reduce thereby presenting a hygienic and conducive environment to the people, which will directly or indirectly increase the life expectancy of the people.

\section{References}

i. Adejumo, A. A. (2008) "Some Thoughts on Affordable and Social Housing in Nigeria", http:/ / www.nigeriavillagesquare.com/ articles/ akintokunbo-a-adejumo/ some-thoughts-on-affordable-andsocialhousing-in-nigeria.html, cited online 10 December 2008.

ii. Agbola, T. (1998): The Housing of Nigerians; A Review of Policy development and Implementation, Research Report No 14, Ibadan, Development Policy Center.

iii. Aribigbola, A. (2006). Rational Choice Model and Housing Decisions in Akure, Ondo State Nigeria. Confluence Journal of Environmental Studies 1 (1) 53-63.

iv. Diogu, J. O. (2002) "Housing the poor in Nigeria: The Integrated Project Approach" Association of Architectural Educators in Nigeria (AARCHES) Journal, 2(1) 1-6.

v. Fadamiro, J. A.; Taiwo, A. A. and Ajayi, M. O. (2004). Sustainable Housing Development and Public Sector Intervention in a Developing Country: Nigeria. In Ibitoye, O. A. (Ed) Scientific and Environmental Issues in Population, Environment and Sustainable Development. Lagos, Graams.

vi. Ibimilua, A. F. (20011). The Nigerian National Housing Policy in Perspective: A critical Analysis. Journal of Social Development in Africa, 26 (2) 165-188.

vii. Ibimilua, A. F., \& Ibitoye, O. A. (2015). Housing Policy in Nigeria: An Overview. American International Journal of Contemporary Research, 5 (2). Retrieved from http:/ / www.cenresinupub.org.

viii. Kabir, O. K. (2004) Low cost Technology and Mass Housing System in Nigeria. Journal of Applied Sciences. 4(4): 565-567.

ix. Kehinde, F. (2010) Housing Policy and Development in Nigeria. In Omotosho, F; Agagu, A. A. \& Abegunde, O. (Eds) Governance, Politics and Policies in Nigeria. Port Novo, Editions Sonoud' Afrique.

x. Lanrewaju, A. O (2012) Urbanization, housing quality and environmental degeneration in Nigeria. Journal of Geography and Regional Planning. Vol 5(16) pp 422-429 December. Nigeria

xi. Olotuah, A. O (2005). Urbanization, Urban Poverty, and Housing Inadequacy; Proceedings of Africa Union of Architects Congress, 23- 28 May, Abuja, Nigeria pp.185-199.

xii. Osuide SO, Dimuna KO (2005): Effects of Population Growth on Urbanization and the Environment in Nigeria. pp. 27-33. In: Proceeding of year 2000 National Seminar on Population, Growth, Architecture and the Environment. Osuide SO (Ed.). Rasjel Publishers.

xiii. Ugonabo, C. U. (2012): Major Challenges to Housing Development and Delivery in Anambra State. Paper Presented at The One-Day Mandatory Continuing Professional Development Seminar, NIESV, Anambra State 